\title{
OFFICIAL PUBLICATION OF
}

IOWA STATE COLLEGE OF AGRICULTURE

AND MECHANIC ARTS

\section{RECOMMENDATIONS FOR FARM DRAINAGE}

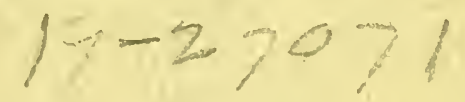

\author{
By \\ W. J. SCHLICK
}

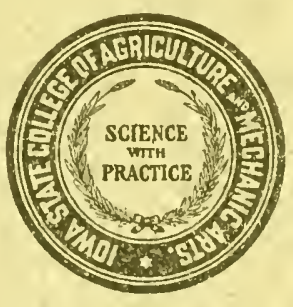

BULLETIN 51

FNGINEERING EXPERIMENT STATION

Ames, Iowa 


\section{PURPOSE OF THE STATION}

THE purpose of the Engineering Experiment 1 Station is to afford a service, through scientific investigations, evolution of new devices and methods, educational technical information, and tests and analyses of materials:

For the manufacturing and other engineering industries of Iowa;

For the industries related to agriculture in the solution of their engineering problems;

For all people of the State in the solution of the engineering problems of urban and rural life. 


\title{
OFFICIAL PUBLICATION OF
}

IOWA STATE COLLEGE OF AGRICULTURE AND MECHANIC ARTS

\section{RECOMMENDATIONS FOR FARM DRAINAGE}

\author{
By \\ W. J. SCHLICK
}

Drainage Engineer

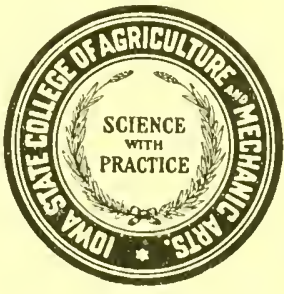

BULLETIN 51

ENGINEERING EXPERIMENT STATION

Ames, Iowa

"Acceptance for mailing at special rate of postage provided in section 1103-Act of Oct. 3, 1917. Authorized Sept. 23, 1918." 


\section{STATE BOARD OF EDUCATION}

Members

Holl. D. D. Murphy, President........................ Elkader

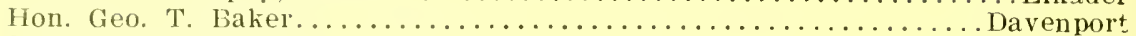

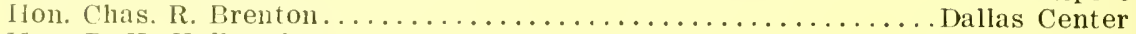

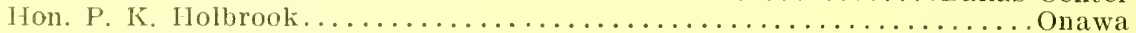

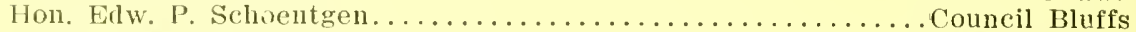

Hon. H. M. Eicher......................... Washington

Hon. Frank F. Jones................................ Villisca

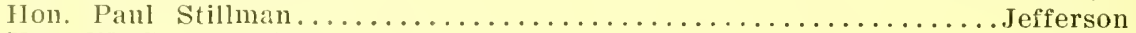

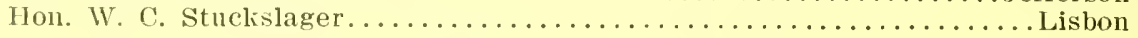

Finance Committee

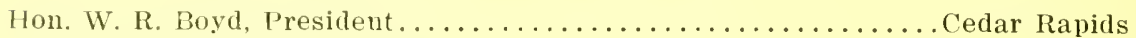

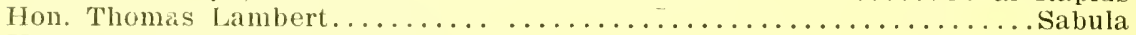

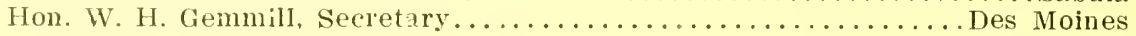

\section{ENGINEERING EXPERIMENT STATION}

\section{Station Council}

(Appointed by the State Board of Erlucation)

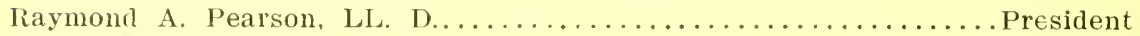

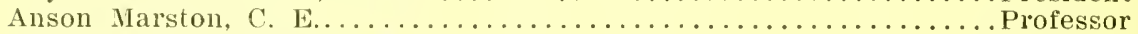

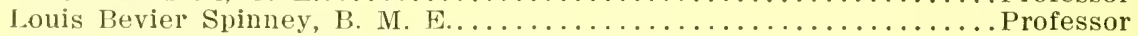

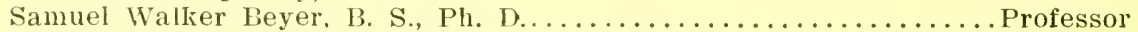

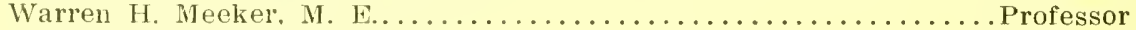

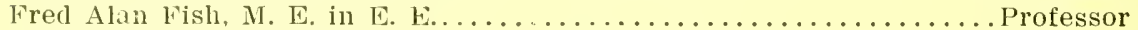

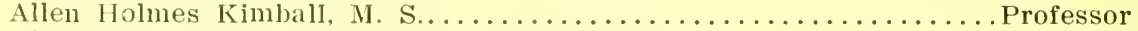
Thomas Harris MacDonald, L. C. E. Chief Engineer, Iowa Highway Commission

Station Staff

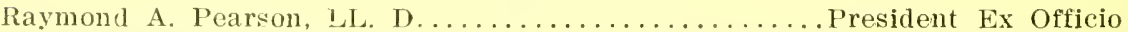
Anson Marston, C E................... Director and Civil Engineer Samuel Walker Beyer, B. S. Ph. D.........Mining Engineer and Geologist Charles S. Nichols, C. E..............ssistant to Director, Sanitary Engineer Louis Bevier Spinney. B. M. E........... Illuminating Engineer and Physicist

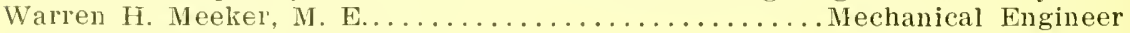

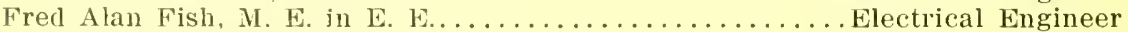

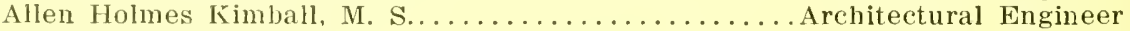

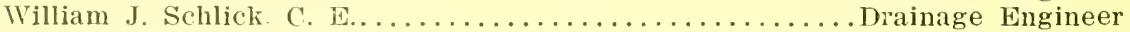

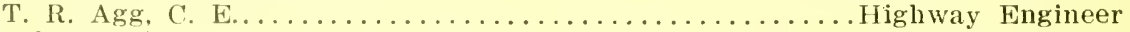

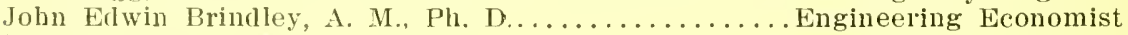

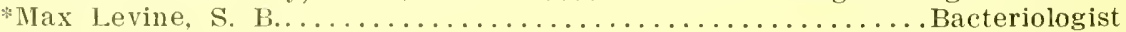

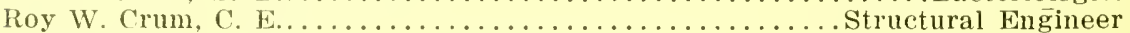

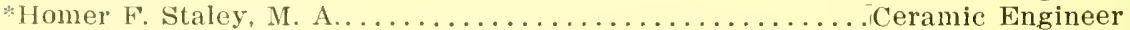
D. C. Faber, E. E............Mechanical, Electrical, and Industrial Engineer

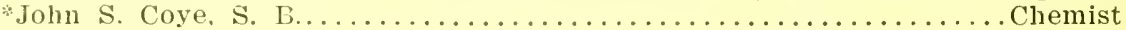

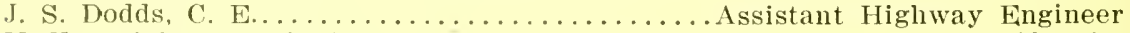

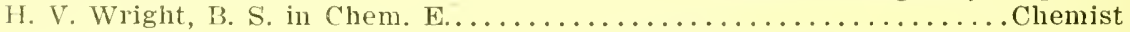

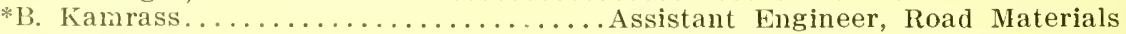

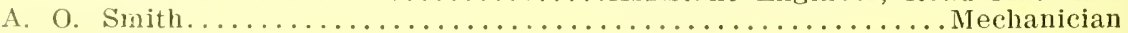




\section{"Don'ts" for the Land Owner}

Don't try to do the work for which you should employ an en* gineer.

Don't let your contractor do both his work and the engineer's. You may reduce the first cost thereby, but the chances are that in the end you will have lost much more than the cost of the engineer's services.

Don't employ any but a capable engineer. The fee for the services of a capable engineer will be higher than for those of a poor or inefficient man, but he will really cost you much less. The mistakes of an incompetent man cost more than the fee of the best engineer.

Don't have your drainage planned piecemeal. If you cannot put in a complete system at first, have the entire plan worked out and then construct it as you are ready. If your work is planned a little at a time the chances are that in the end you will have an inefficient, overlapping system.

Don't destroy the records of your drainage system. If you have a complete record of those drains which have already been constructed, it will be easy to plan your additions so that they will render efficient service. This record will also be of considerable value if your farm is offered for sale.

Don't expect yourself or your engineer to be able to look at a tile and judge its strength. The appearances of tile in this respect are deceiving. Have a sufficient number of them properly tested to assure yourself that they meet your requirements.

Don't try to save money by using poor tile or poor construction. Low first cost may mean a high maintenace couî with small benefits.

Don't be discouraged if your drainage system does not come up to your expectations the first season. All soils, and especially the "closer" ones, drain more readily the second and third years than they do the first.

Don't be satisfied with any system that is not designed and superintended by a capable engineer, and constructed of good materials by a reputable workman. 


\section{Recommendations for Farm Drainage}

Farm chainage is responsible in large measure for the high prodnetivity of lowa soil. Not only has it greatly increased the yield of many thousands of aceres of good laud, but it also has entirely reelaimed many other thonsants of ateres which originally were untillable. Farm drainage, probably more than any other ont extensive operation, has added mormousty to lowa's wealth, both rural and urban. It is, therefore, of common interest to layman and engineer alike.

While this bullotin is preprared for the general guidance of landown(ris who wish to construet lam drainage systems, it contains information needed by the yourg trainage engineere. Some paragraphs are really adderessed to the engineser, but they should also serve as a guide to the landowner in the formalation of his plans for the proposed drainage system, and later enable lim to issue intelligent and colrect instructions to his engineer.

These recommentations are intended to give a good general knowferlga of the main leatures of the farm drainage system. Should the reader desire to make a more detailed study of the subject, including the results of drainage investigations, he should write for Bulletins 50 or 52 of this station.

\section{DOES UNDERDRAINAGE PAY?}

Every landowner who has given any thoughtful obselvance to this smbject will answer this gnestion in the affirmative, and the more thoro has been his study of the question the mole emphatio will be his answer.

During the reconstruetion period, when our farm prodnets must be sulficient not only for our own needs but for those of portions of wartorn Europe as well, it is the duty of every landowner to increase the probluction from his land to the naximum.

During the spring of 1917 the witer put the above question to a number of owners and tenants of tiled land in north-central Iowa. They estimated that the molerdrainage had incerased the prodnetion of corn from ten to twenty bushels pere aces on land which had formerty prodneed a partial erop in ary years. In other eases they stated that land which had formally been too wet to cultivate was prodicing, on an average, as mueh as the highere and dryere land.

lin answel to another question, they stated that they eould begin euttivation three days to fourteren days earlier in the spring heeanse of the drainage: and that after a rain they conld cultivate their erop on mderellained land in about one-thiri to one-half the time they had to wait for undrained land to become dry enough to work.

\footnotetext{
* Bulletin 50 gives discussions of the forms of soil-moisturc, their relation to crop productron and drainage, the movenents of ground water to and in the drain, and the design of the drainage system.

Bulletin 52 includes data for sexeral typical Iowa underlrainage systems on rates of runoff and the fluctuation in the ground water level, and their relation to the spacing and depth of laterals.
} 
In none of these ficlds were the drains spaced closer than one hundred feet, so that the eost of drainage per acre underdrained was probably not more than forty dollars in any case. Even with corn at only fifty cents per bushel, which is only about one-third the present market priee, the ten bushel increase dne to drainage will pay the interest on the investment and leave enongh smplus to repay the principal within a few years, and do this with a decrease in the cost of producing the erop.

Does tile drainage pay? Study it: watch the results in your neighbor's field: the result will be an enormons incrose in the production and wealth ol Iowa.

\section{THE EMPLOYMENT OF AN ENGINEER.}

It is especially recommended that the landowner employ a competent engineer to plan his thainage system, and to superintend its construction, or at least to speeify the materials and general methods of construction. The agriculturist should no more expect to act as his own "mgineer than as his own attorney. In either ease his lack of speecial knowledge will probably result in finaneial loss. The drainage system is an investment: it is constructed only when the landowner believes that it will yield good refums on the amonnt invested in it. Becanser the engineer" gives the solution of each problem the benefit of his special knowledge and hases his conclusions mon the acemate information obtained from a survey of the area to be drained, the amount expended for his services will yieht far greater returns than any other part of the cost of the system.

\section{PLANNING THE SYSTEM.}

A correctly planned and construeted farm drainage system is much more nearly everlasting than any other farm improvement, and has a mueh lower ammal maintenance cost. The useful life of such a system will be terminated only when the knowledge of molerdrainage has adranced to a point where it will be profitable to replace the old system with a new and more efficient one.

In planning his drainage system the lambower should look to the future as well as at the present and not be "penny wise and ponme foolish" in attempting to rechere the cost of his system. A few dollars saved in time or expense in designing the system may eause an annual loss of a greater amount in the returns from the system. Every detail of the system should be earefully studied and inrestigated hefore the final design is decided npon. Sule study will result in a more efficient șrstem at a deereased cost.

\section{THE OUTLET.}

The outlet is the first rssential of a good underdrainage system. No matter how well it may he designed and construeted, any system of m- 
derdrainage which is deprived of a satisfactory outlet will fail to give satisfactory service. Therefore, the first step, in planning underdrainage for any area is to locate, definitely, the most suitable outlet.

The ideal ontlet provides for a free flow from the main at all times; allows the construction of the main drain at a good grade; and requires a depth of eut just sufficient to permit of ready flow from the submains and laterals. It may be either a natural drainage chamel, a commty drain or an open titch. Usually a small amount of reconnoissance by an experienced engineer will enable him to tecide upon the feasibility of any proposed outlet. There may be cases, however, where the capacity of the outlet will need to be earefully investigated to determine whether it will eare for the flow reaching it without submerging the tile outlet too greatly or for too long periods. This should be done after the tile system has been designed tentatively.

\section{SURVEY AND PLANS.}

Ilaving decided upon an outlet, a complete survey should be made of each area which may eventually be included in the district served by the one system. A complete trainage system can then be ontlined. It may be that the landowner will wish to construct at first the muderdrainage for only a small part of his total area, but if the plan for the complete system is worked out in the begimning any part may be constructer at any time and yet contribute toward the finally complete and efficient system. If the work is planned only a litttle at a time, and so construeted, the result will very probably be a collection of overlapping small systems which make one large, inefficient system. As each section is construeted, it should be noted exactly on the plan so that adclitional work may easily and aceurately be joined to that already construeted.

\section{LOCATION OF LINES OF SYSTEM.}

The location of the main drain will be controlled largely by the position of the ontlet, the size, shape and slopes of the area to be drained, and by the location and depths of the laterals. The main and submains should be so located as to provide good grades ant to permit easy construction and efficent operation of the lateral system. In large measure, the location, alignment, depth, and grade of the main and submains will control the form, depths, cost, and efficieney of the lateral system. So far as possible the mains should follow the line of the lowest elevation thru the area to be underetrained, so that the laterals will have a good fall and yet not be too deep.

\section{THE LATERAL SYSTEM.}

Considerable study is often necessary to plan a lateral system which wrill best suit the needs of the area to be drained. This study should be 
complete, as the thoroness of drainage will depened very largely upon the effectiveness of the lateral system.

Certain general principles are found to govern the spacing and depths of lateral chains. 'T'hese are particularly applicable to different parts of the sistem located in the same gencral area.

The flow of water thru the soil to the drain is governed by the same laws which control the flow of water thru the drain, or in a ditch along the road. The rate of flow in either case is dependent upon the fall or grade, the roughness of the sides of the channel and its size and shape.

'The rate of runoff from the tilessitem is but the rate at which the water moves thru the soil to the dian, providing that the tile lines have a large enough capacity to care for all the water as it reaches them As will be seen from the diagram in Fig. 1, the ratertable rises in a curve from each drain and reaches its highest point midway be. tween two adjacent drains. Since for any field the size and shape of the soil pores, and the resistance to the passage of the water thru them, are the same at any one time for different spacing and deptlis of later. als, it follows, that, in general, either decreasing the distance between aterals or placing them decper will increase the slope from the crest of the watertable to the train, so long as the crest of the watertable rises to the same elevation in respect to the surface of the ground. This will increase the rate at which water reaches the drain.

lyy increasing the depth of laterals, and accordingly loworing the gromndwater hine after each rain, a larger volume of soil is freed from surplus moisture. As it is only in that portion ol the soil which is free from sumphs moisture that plant roots ean obtain food and live, it becomes one of the important functions of underdrainage to maintain the groundwater line at each such level as will best serve vegetation.

Any change in the system hy which the groundwater ean reach the malerdrains more rapidly will hastrn the drying of the soil after rains and permit of earlier cultivation.

The effects of spacings and depths of laterals may be summarized as follows :

Decreasing the distance between drains not only increases the rate of runoff but decreases the time necessary to remove the surplus moisture after each rain.

Increasing the depth of the drains increases the rate at which the drains lemove water l'rom the ground and lowers the arerage level of the groundwater, thus provinling a lasger food supply for growing (*)ops.

A correct molerstaneling of these principles and the diagram in Fig. 1 will assist the landowner in deciding upon the general leatures of a system to selve bis area. In consielering different spacings and depths it shoukl be remembered that the rate of movement of water thru a close, fine-grained clay soil is always less than that thru the more opeis loanl. This point should be considered when contemplating any in. crease of elepth which will place the laterals in a more impervions soil. 


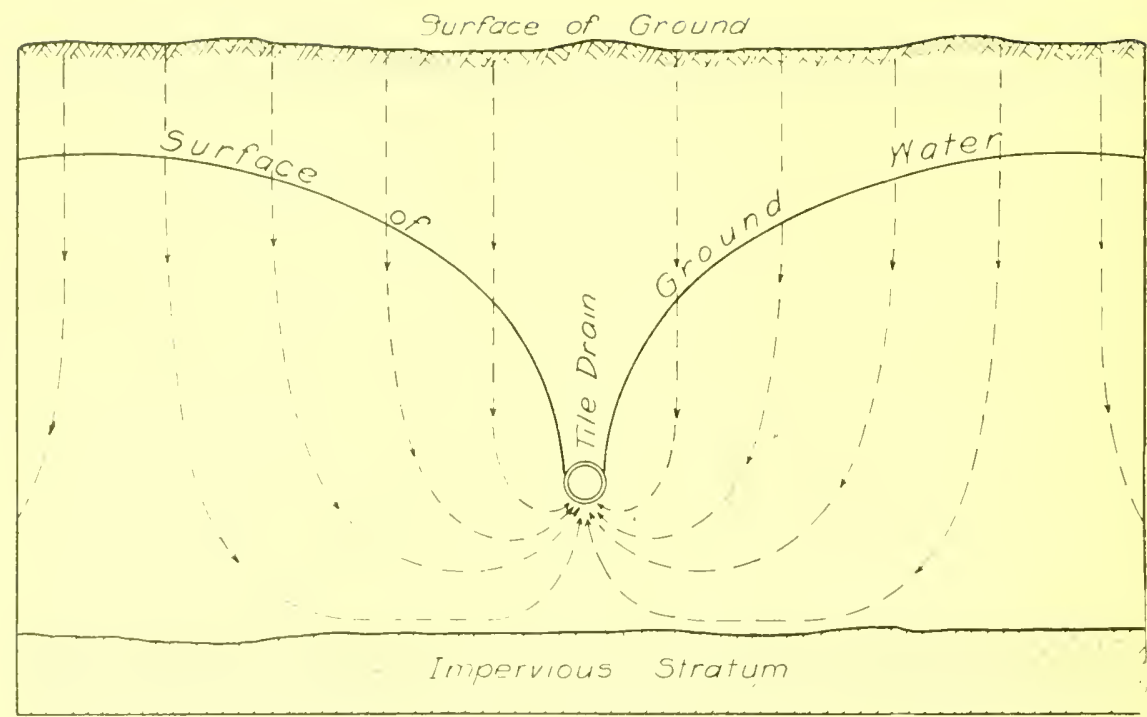

Fig. 1. Diagram lllustrating the Movement of Water from the Surface to the Drain.

The increased depth might thus be a detriment for the first few years. It is cloubthul, howerer, if there are any soils in Iowa in which the lateral drains shonlel not be placed as deep as reeommended hereinafter.

Thus it is seen that the suceess of any underdrainage system depends upon the firedom with which water may pass thru the soil. Many persons hold the eroneous belief that the water falling on an molerdrained area moves directly from the surface to the top of the drain. such is not the case. No water or tinarily enter's a drain from the top exeept that which falls mpon the smeface directly above the tile, and then only when the soil conditions are such as to allow of a nearly vertical pereolation from the smefaes to the underchain. The path taken by a drop of water in passing from the surface to the drain is illustrated in Fig. 1 The surplus moisture in the upper layer's of soil, or upon the surface, moves as nearly directly downward as the soil formation will allow, until it reaches the level of the gromelwater. It then moves downward and laterally in a cmred path to the drain, entering it from the bottom. Its movement after reaching the grommiwater level is somewhat meertain, but Fig. 1 illustrates the general course of this movement.

In speaking of the relative efficiencies of different systems, it is often stater that the underdrains in one field "draw" better or farther than those in another field. Actually the drains do not draw at all, if by that it is meant the tile exert a pull teneling to suck the water out of the soil pores and into the drain. The modertrains serve simply as colleeting channels or outlets for the pereolating water. If one field is drained 
farther back from the lines of the tile than is another, it signifies simply that the conditions of the soil are such as to camse a more reaty movement of the groundwater to the tile in the one field than in the other and that the tile in the better drained fleld have ample capacity to remove the water as it reaches them.

Laterals spaced from 50 feet to 100 feet apart in ordinary Towa soils will give adequate drainage for tield crops. If the soil is mmsually close, or if the drained area is to be used for truck coops, the laterals may need to be as close together as :3:3 feet. If the soil is musually open, or if there is a large smiface rumoft from the area to be draince, the distance between the laterals may be increased to 150 feet, and in very rare cases to 200 feet. Hlowever, spacings larger than 100 feet or smaller than 50 feet are not now desirable for the average soils of lowa.

In most Iowa soils, laterals laid at a depth of abont fonl feet will give the best service. In a few eases where the sub-soil is vely impervions up quite close to the surface, it nuy be desirahle to use a less depth, hut even in the closest clay it generally will be found advisable to use this depth and decrease the distance between the laterals. It is well known that mderdrainage will show far greater results the second or thirel year than it does dming the first year, and it is donbtful if there are any Iowa soils which will not drain satisfactorily after the first three years if the system is properly designed and constructed and the laterals laid fonr feet deep.

Relation to Efficiency and Cost. In any underelrainage system the separate parts must be comelated if the whole is to bo eflicient and its cost a minimum. Each part must be considered not only by itself, but in its relation to every other part. By such analysis it often appears atrisable to change the tentative location of the main, aither in alignment or in grade, so as to serve, to the best adrantage, all the laterals of thesestem. It should also he borne constantly in mind in locating the varions lines of the system that the most economical arrangement is usually that one having the least number of jumctions. At each jumetion point tle land is drained by both the joining lines, so that a few long laterals are rather to be desired than are a larger momber of shorter ones. The above are general principles, not iron-clad rules; each system must be designed to meet the special needs of the area which it is to hrain.

Relation to the Area to be Drained. In slongh ol swamp areas of in regular shape, it is usmally advisable to rum the main up the general comse of the low area and hrain the arms by laterals. For wider and more regnlar slonghs a main may follow up the center, with parallel laterals branching at approximately right angles on each side, or a 11111 ber of long parallel laterals may he laid up the slough and all joined to a main at the lower end. Luless the slongle is too wids or too long. the latter sistem will probably be the cheaper.

The seepy places at the bottom of a slope can best be drained by lay- 
ing a tile so as to intercept the seep water at the foot of the slope. Such a drain should have a good grade and should follow the foot of the slope as closely as is practicable. Its depth should be determined hy the depth of the porous stratum from which the water seeps.

The melerdrainage of areas adjacent to a natural drainage channel $\mathrm{or}^{*}$ open ditch can usually be accomplished best by the construction of a nmmler of small systems, each serving a small area. All the tile in these small systems may be of small size, thus redueing the total cost below that of one large system. However, this scheme can be followed only when the water course will furnish a good outlet for each of these small systems.

\section{SURFACE DITCHES AND INLETS.}

When the area to be drained receives considerable surface rmoff from adjoining lands it is sometimes atvisable to provide shallow sur. face clitehes to eare for this surface flow. Such ditches will nsually follow the lime of the lowest elevation. They should be very shallow, not more than one or two feet deep, but shonld be wide and should have very f'lat side slopes. Such a ditch will aid materially in caring for the snrface flow in the spring and during heavy storms and will not interfere with the cultural operations. It is desirable to furnish ontlet for these ditches through an inlet and a short line of tile, whether the ontlet is a large tile, an open ditch or a natural watercomrse. Such construetion is rery neeessary if the flow in this shallow ditch is to empty into a comnty tile drain. If the diteh is to empty into an open channel some protection is necessary or a leep ditch will graclually be cut back into the field.

These shallow ditches should never be used except across flat ficlds. If the general surface slope is at all steep such ditches are not necessary and if constructed wonld soon wash ont so as to become impassable with field implements.

It is often desirable to construct inlets for the quick removal of water which collects in the depressions or ponds. Such inlets should be of Inrable construction, and should be so designed and located as to readily admit the surface water to the drain and still prevent the admission of trash carried by the surface flow.

Probably the most inexpensive surface inlet can be constructed by filling in over a short section of the drain with crushed stone or coarse gravel. Snch an inlet will be satisfactory as long as the amount of water to be earried to the drain is quite small. Some landowners favor the construction of such inlets wherever the dead-furrows cross a line of tile. In most cases where it is necessary to construct surface inlets the amomnt of water to be removed will be large enough to make it advisable to use some other type than the crushed stone inlet just described. Inlets may be constructed of brick in the same way as for sewers or of tile or sewer pipe. For farm drainage systems it is probable 
that the most economieal, satisfactory inlet can be bnilt by replacing: one length of drain tile with a sewer pipe ' $\mathrm{T}$ and homilding the vertieal leg to the surface with sewer pipe. The top of this rertical section should be fitted with a wire or east iron grate.

\section{UNDERDRAINGAGE OF UPLANDS AND SLOPES.}

In addition to removing the smlplus moistme, underdrainage is desirable and valuable for mpland tracts as well as for level or swampy areas because of its action upon the character and formation of the soil. The smpply of availahle moisture in upland soils, and especially in the slopes, is msnally small. Underdrainage will so alter the physieal character of these soils as to increase their capacity for that form of moisture which is valuahle for plant use.

Upon the slopes of areas not underdrained much of the water from rainfall eseapes as surface rmoff before the soil has time to take it up. 'The moving water collects in the small depressions and forms into rivenlets which flow down the slopes. These small streams carry away much of the surface soil and in time wash ont large gullies. Upon the more gentle slopes much of this erosive action may be prevented by the construetion of propery designed undertrainage systems. The action of the muderdrains not only increases the reservoir capacity of the soil but also the rapidity with which the water will pass from the surface to the subsoil. Throngh these two agencies the amount of snrface runoff is materially lessened and a corresponding reduction effected in the erosive action.

\section{VERTICAL DRAINAGE.}

"Vertical drainage" enntemplates the use of wells as drainage outlets. One system of vertical drainage eousists in constructing numerous comparatively small amd shallow cased wells each of which is designed to serve as both latrals and ontlet main of a small system. The smplus soil moistme is supposed to move throngh the soil pores to these wells and from them to some porous undereround stratmon throngh which it finds a final outlet. 'This system will probaldy be less costly than tile drainage but will he mucl less efficient and its use can not berecommended.

In the other, and more common system of "vertical drainage" wells are used as ontlets for tile drains. 'This system has not proved miformly successful, and so camnot he recommended for general use. ln some cases an ontlet for a farm drainage system can be secured economically in this way, but it is practically impossible to foretell the suceess of such outlets. Some wells which at first afford very sat isfactory service fail later to eare for the flow of water from the drains. In some loealities one well will prove amply sufficient, while another, nearby, will be entirely inadequate. If no satisfactory ontlet of one of the nsmal types can be seenred, this means may be tried if, from the engineer's 
knowledge of the ristrict, it seems certain or probable that porous underground stata, of sufficient cross section to carry away the drainage water, can be reached within reasonable distance.

The cost of wells for drainage ontlets will depend npon the size and depth of the wells and the nature of the material which must be excavated it is, therefore, wise to determine quite definitely what is involved before deciding to construct such a system.

\section{SIZE OF TILE.}

'The following discussion of runoff and the methous of calculating sizes of tile is intended particularly for the young drainage engineer. It will prove of value to the landowner also, by explaining how his system shoulel be designed and by fomishing him with a means of understanting the decision of the engineer upon questions which may arise regarding the sizes of tile to be used.

Runoff. The runoff coefficient adopted will control in a large measure the eost of the system and the effieiency of its operation. It should provike a rate of runoff large enough to insme adecuate drainage for heaviest storms to be expected year after year, tho perhaps it is not always necessary to provide suffietent capacity for the extreme maximum during those extraoldinary storms which oceur, say, onee in ten wr fifteen year's.

'The rate of rmoff from underdrains will vary directly, tho not necessarily proportionally, with the amomt and character of the rainfall. Localities subject to heayy rainfalls will have a rate of runoff larger than will other loealities having less rainfall. 'The nature of the storms also, will have a marked effect upon the runoff from underdrains. For instance, a rain of one inch falling in a short time, as in smmmer thmdershowers, will cause a much smaller total rumoff from mordrains than one of an equal amount falling as a gentle rain for twelve or twenty-fom homrs. In the ease of the heavy shower the water reaches the earth much faster than it can be taken up by the soil, and, of necessity, much of it must r'm away over the surface. However, the rainfall in Iowa is of sufficient iniformity that, so far as this factor is concerned, the runoff coefficient will be the same for all portions of the state.

The rate of runoff is markedly alfected by the size, shape and slope of the watershed or drainage area. Other things being equal, the rate of runoff from a large area is somewhat smaller per acre than it is from a small one, and that from a long, narrow watershed is somewhat less per acre than from one more nearly cireular. However, the size and slope of the watershed affect the rate of surface runoff more than they do the rmoff thru underdrains. As a matter of fact, the rate at which the water moves thru the drains is so much greater than that at which it moves thru the soil to drain, that the affect of these factors is comparatively small. 
In deeiding upon the runoff eoefficient, the relation of the size, shape and slopes of the mitiled eontributary watershed must be eonsidered in eomnection with the area actually to be muderdrained. If the untiled atjacent area is comparatively large and las fairly steep slopes, the surface and undergromud rumotis on to the flatter tiled area below are equivalent to so much additional rainfall, and must be taken into account in designing the drainage sistem for the flatter area.

The rate of runoft is considerably affected hy the character of the soil. In elose soils, such as clay, the water will not pass down to the drains as rapielly as it will in a more open soil sueh as loam. It is for this reason that tile in clay soils are laid with relatively close spacing, and generally should be knpt at the top of any very imperious subsoil stration.

The rate of rmoff will vary with the seasons. A rain of a given character and anomnt in the early spring will cause a much larger rate of rumoff than if it ocemred in July or August. During the warm months, when the natural craporation from the gromel smrlace is large, and when the crops are growing rapielly and drawing large amounts of water from the soil, the gromndwater is maintained at a comparatively low level, thus creating a large storage reservoir in the soil. Under these conditions the soil absorbs and holds what water is necessary for plant life, and accordingly decreases the rate of runoff thru the drains.

In Iowa a eommon practice has been to use a runoff eoeflivient which will provide for the removal of a $1-4$ inch depth of water from the drainage area in 24 hours, though of late, there is a tendency among drainage engineers to provide for larger capacities in some instaners. No one coefficient is truly applicable to all drainage systems in the state. This low value may be correet moler some conditions, but is probably smaller than should be used for a great many systems. So if an average value is to be stated, it seems proluahlo that $3-8$ inch will he more satisfactory than $1-4$ inch. In reality the maximm rate of aetual melerdrainage rumolf will vary, meler different conditions, from 1-4 inch to more than 1-2 inch. All the factors affecting the rate of rmoff must be considered in deciding upon the correct value.

If the rate of rmoff is equal to the removal of $1-4$ inch elepth of water ler 24 hours, the flow will be 0.0105 eulice feet per secomel trom each acre. The total flow from 100 acres would thus be 100 times $0.0105,01$ 1.05 eubie feet per second. When the rate of 1 moffe is $5-16$ inch, 3-8 inch or 1-2 inch, the rate of flow in cubie feet per second, from each acre will be 1 1-t, 1 1-2 or 2 times 0.0105 , respectively.

Calculating Sizes of Drains. After the system is all phanned as to location and probable grades of the tile lines, and the proper runoff

A full discussion of the factors affecting runoff is given in liulletin 50 . There is also given in Bulletin 52 a description of some typcal underdrainage systems and runoff data for them. These are for those who wish to give these matters more thoro study than is possible here.

* See recommendations for values of runoff coefficient, Bulletin 52. 
coefficiont has been adopted, it is then necessary to determine the sizes of tile which will be recuired for each line. This involves calculating the capacities of different sizes of tile at the grade which is to be used, until the proper size is found to eare lor the runoff. The experience of the engincer will enable him to estimate so elosely at first that he probably will need to calculate the eapacities of but two or three sizes. Probably he will also save himself much labor by the use of thoroly reliable tahles and cliagrams. Ilowever, these should be used only by the engineer who understands them fully, and knows them to be aceurate.

Most trainage engineer's nse either Poncelet's formula, Elliott's Modifications of Poncelet's formula or Kutter's formula with the value of the constant. "n" determined by assumption from a study of experimental data, for ealenlationg the capacities of tile drains. Practically all hydranlic engineers who have investigated the flow of water thru pipe lines similar to tile drains, have adopted Kintter's formula as being the most accurate of all those in general nse. Each of Elliott 's formulas is Ponedet's formula with factors added to care for an assumption that the water in the main is flowing under pressure, or mnder a head greater than that due to the slope the line of tile. This increased head is provided for beeanse of a belief that the water in the soil over the npper ent of the main, and that flowing in the sulmains which have steeper slopes than the main, cause a larger flow in the main than that due to its grade.

The capacity of a line of eight inch tile is nearly one-third more ac: cording to Elliott 's formula, as it is commonly used, than that given by Kutter"s formula with the value of "n" taken as 0.015 . This difference decreases as the size of the tile increases, the two formulas giving practically the same capacity for a line of 24 inch tile.

In his hook, "Engineering for Land Drainage," Mr. Elliott gives sereral modifieations and states that each is applieable to a certain condition. It has heen common praetice with many engineers to use one of these motifirations, or a table prepared from one of them, for all tile lines, mains, submains and laterals. This practice is not fair to either the formula or to the landowner.

All engineers who have measured the discharge from tile mains know the discharge is sometimes larger than the caleulated eapacity. Investigations male by the Iowa Engineering Experiment Station have proven that tile systems in Iowa often discharge at a rate required to remove 1-2 inch, or inore, in depth from the drainage area in 24 hours. 'This being the casce, it is more reasonable to assmme that the inereased flow is due to the fact that the water reaches the laterals and submains more rapitly than the main can carry it away, thus backing the water II) in the subnains and increasing the hydraulic head upon the main, than to assume that the large discharge is due to a head caused by the water in the soil above the upper end of the main. As long as tile systems are designed for a rmoff coefficient of $1-4$ inch per 24 hours, which is known to be mich less than the actual maximum rate of rumoff, it seems needless to attempt to explain the large discharge in any 
other way than that it is due to an increased hydranlic head cansed by the water reaching the submains faster than the main can carry it away when flowing under gravity head.

So long as the tile chraus are large enough to earry away the water as fast as it reaches them, the water flowing through the soil has, in effect, a free ontlet and cannot increase the hydraulie head or slope of the flow through the drains. On the other hand, if the water ean pass thru the soil to the drain more rapidly than it ean flow away through the drain, water is being lede back because of the insufficient eapacity of the drain and the condition in the drain is similar to that in the diseharge pipe leading from an elevated watel-tank. If the drains are large enough to carry away the water as fast as it reaches them, the assmomption upon which Elliott's formulas are based can nerel he true. In one case where the measured discharge showed the mof coefficient to be very large, and where the main was known to be sureharged (the water lose to the surfate at the junction of the sulmains and the main and was backed np in the submaines), the coefficient of loughness ("n" in Kutter's formula) was computed using the stope from the surface at the junction of the submains and the main to the smiface of the water at the outlet of the main. "The value of the coefficient "n" in this ease was just slightly less than 0.012, which is larger than has beren foumel for some well laid trains when not flowing full. It is known that this particular line of tile was well laid, so it does not seen incorlenet to assume that this large flow was due simply to the increased hychanlie. grade.

It is beliered that Kutter is formula is the most rational one for use in the resign of tile drains and it seems certain tluat if it is in error that the error is in the right direction. Kutter s formula will require slightly larger tile for the farm system than will Elliott's formma, which fact alone is sulficient reason lor its use. Largen sizes of tile are nerded in lowa drainage systems and ane now economically feasible.

For the reasons just stated only Kntter's formula is given leere. It is assmmed that each dramage engineer will have aceess to books or publications giving any formula he may desire to mse.

Kutter is formula :

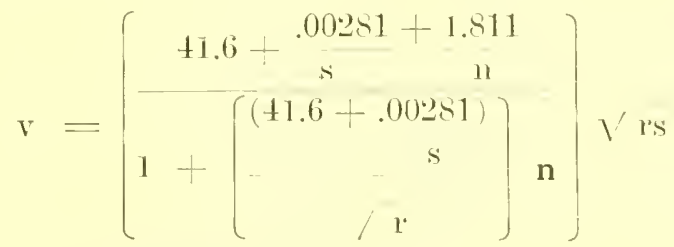

Where, $s=$ the slope in feet per foot

$r^{*}=$ the mean hyclranlie rachins in feet, or the area of the

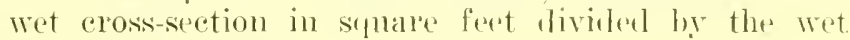
primeter in fuet.

$\mathrm{n}=$ the coefficient of roughness. 
The discharge, then equals the protuet of the area of the wet erosssection and the velocity.

Coefficient of Roughness. From the results of actual drainage investigations it appears that for average Iowa drains the average value of the coefficient of roughness " $n$ " in Kutters formula is 0.015 . Some drains were found where this coeffieient had a lower value, but it does not seem wise to use any lower value in tesigning the drainage system. Engineers have not infrequently used too low values for this coefficient in the past with the unfortunate result that they selected too small tile.

Use of Formula. In using Kinter's formula, the hydraulic grade should be carefully determined and the proper value of the coefficient of ronghness decided upon. Kutter's formula may be easily expressed by use of diagram such as shown in Fig. 2, from which the eapacity of any size of tile at any grade can readily be taken. In using this diagran it should be kept constantly in mind that the hydraulic slope or grade is to be used always and that this hydranlic slope may differ from the actual slope or grade of the constructed line. In the case of submerged outlets, for example, the hydranlic slope will often be much less than the grade of the tile.

Use of Diagrams. A diagram like that in Fig. 2 is prepared by computing the capacity of the different sizes of tile at different grades when flowing full, and then platting them in suitable arrangement on a logarithmic chart. 'The diagonal lines, marked with the size or diameter of tile, represent the capacity of the tile when flowing full. To find the capacity of any tile line, follow up the line representing its "Slope in Feet per 100 Feet" (grade) until it interseets the diagonal line representing that particular size of tile. From this intersection trace the horizontal line to the left and from the scale at the side of the diagram read the "Discharge in Cubie Feet per Seeond." At the same height on the right of the liagram will be found the number of acres drained, whether the runoff coeffieient be $1-4$ inch, $5-16$ inch, $3-8$ inch, or. 1 -2 inch.

To make this operation clear, take the following concrete example: Assume a line of 15 -inch tile laid at a 0.10 per cent grade (a fall of 0.10 foot per 100 feet.) 1t is desired to determine how many acres this main will serve. By following up the vertical line representing a slope of 0.10 till it intersects the diagonal line maked, 15", and then following the horizontal line to the seale at the left, it is found that this tile has a eapacity of 1.52 enbic feet per second. By following the same horizontal line to the scale at the right side of the cliagram, it is found under " $R=3-8$ inch" that at this rate of rumoff this drain would care for the flow from 101 acres. If the rate of runoff were $1-4$ inch, this line of tile: would eare for the flow from 153 acres.

'The landowner is especially warned against estimating the grade at which his tile may be laid and ealculating the sizes required when using 
this estimated grade. It is impossible to correctly determine the grade for any line withont survey notes. It will be seen from the diagram in Fig. 2 that the eapacity of a tile changes very rapidly with any alteration in its grade.

\section{THE CONSTRUCTION WORK.}

It is not intended that the following recommendations for tile drainage construction shall serve as complete construction specifications. They will, however, give the landowner a general idea of the class of construetion which he should have in his drainage system.

\section{SPECIFICATIONS.}

After the design of the system has been completed, the enginem. should prepare a set of specifications which will set forth clearly how the work is to be done and what materials are to be used. For the litter purpose the adoption of the 1916 standard specifications for 1)rain Tile* of the Ameriean Society of Testing Materials is strongly recommended. They were adopted by a committee composed of able men representing the engineers and the mamnacturers, and the committee's resport was later adopted by the society. The engineer should specify that the drain tile used shall conform to the requirements of these specifica tions. In addition: (1) he should prescribe the elass of tile; (2) nuless shale and fine clay tile, surface clay tile and concrete tile are all acceptable, he must provide for excluding any raw materials to which he objeets; (3) if he desires to hold the seller responsible for furnishing tile strong enongh to obviate eracking in the diteh under reasonable treatment he must so preseribe, fumishing information as to witth of ditch at the top of the tile and the depth and character of filling.

\section{KIND OF TILE.}

The engineer should so word his specifieations that they will eall for tile whieh will meet certain stated recunirements; he should speeify the quality of the tile rather than the methods or matrials used in their mamufaeture. Good tile, whether they be mate of elay or of concrete, should be required for each system. Poor tile of any kind are undesirable and in the long ron will prove much more eostly than those of a good grate.

Well-made conerete or clay tile can be purehased anywere in the Mississippi Valley at present at reasonable prices . With standard speeifieations and the standard method of testing, engineers can now govern the quality of tile for any drainage project. 'There is, therefore, no excuse for using a poor product.

*A reprint of these specifications may be obtained upon request addressed to the Director, Engineering Station, Ames, lowa. 


\section{DIGGING TRENCHES.}

The trenches may be dug wither by hand or by machinery, the most economieal method depending upon the amount and location of the work. The tractor trenching machines have been perfected so that they will operate satisfactorily in nearly all soils and to any depth usually required for farm drainage work. Howerer, with these machines it is msually necessary to finish the bottom of the trench with shovels or tile scoops, altho the smaller sizes of tile may be laid in the trench as it is dug by the machine, provitling the bottom is true to grate and the depth of fill over the tile is not over six feet. For tile larger than 12 inches in diameter and where the cover over the tile is more than six feet it will be better to finish and shape the bottom of the trench by hand.

The trencli shonld be dug from the outlet upstream and at a uniform distance to one side of the engineer's stakes. Care should be taken not to disturb the stakes, as they are for use in grading the bottom of the trench. When it is neessary to make a change in direction, this should be done in a regular curve and not as a sharp bend.

In digging deep trenches in some soils it is necessary to sheet and brace the sides to prevent caving of the banks. It is seldom, however, that trenches for farm dramage are deep enough to make this neeessary. As soon as the tile are laid and blinded the sheeting may be pulled and used in other places.

The trench bottom should usually be shaped with a shovel or tile scoop so as aceurately and uniformly to bed each tile for at least 60 degrees of the onter circumference and for its full length. A more careful bedding than this will not usmally be required in any but Commty Drainage Distriets. Howerer, il a more careful bedeling is required. the bottom of the trenely should be shaped acemrately to fit at least the lower 90 clegrees of the ontsiele of the pipe, using care to secure a linm bearing at the outere edges of the bearing area.

The angineer should specify not only the width of the trench for the different sizes of tile to be used, but also the shape of the trench bottom. The trench should be no wider than is necessary for economieal digging ant for pipe laying, usnally six inches wider than the ontside diameter of the tile.

\section{LAYING TILE.}

The tile laying should begin at the outlet and proceed upstream, eare being used to keep the tile at all times true to the aligmment and grade prescribed by the engineer. Adjoining tiles should be laid so that the crack between them will not be over $1 / 4$-inch wide. All cracks wider than this should be covered with pieces of broken tile.

As soon as the tile are firmly bedded in the correct position, earth should be placed aromed them to hold them in places. Where especially carefinl bedding is required the earth should be placed around and mo- 
der the sides of the tile by hand, and tamped linmly in place.

When tile are laid in "mmong same" they shenld be laiel mpon, and

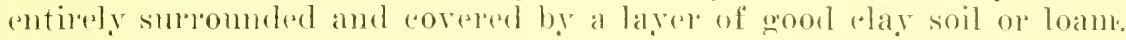
In some cases it may be meessally to use a mole expersive type of construction, such as plateing the tile on a layere ol wild hay or mone petanks, or to wrap each joint with a steip of light-weight rool'ing.

As soon as the pipe alle laid and inspereted, they shombl be blinded ly placing top soil aromed them and orer them to a depth of one foot. ln cold weather this shoulel be done as soon as the tile are laid, using suffieient eapth to prevent freezing of the soil aromet the tile. Lom or

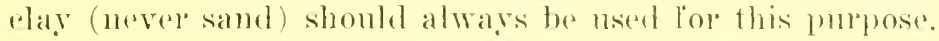

\section{BACK FILLING.}

At least wae foot of loose earth should be plated upon the blinding besfore any large stones or pieces of frozen earth are put in the ditch. Alter this one foot layer is in place, the pemaning bate filting may be done in any way desired. This is nsmally most economically accomplished with trams and some form of serapers, altho with narrow and

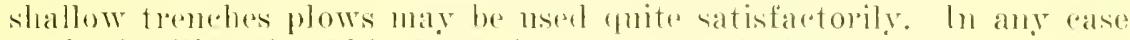
the back filling shomed be heaped mo orep the drain so that when it has settled the tremely may he full.

\section{PROTECTION OF OUTLET.}

The main will often discharge into an open eliteh or natural watere course, the hankis of which are suljecet to arosion. Where the flow from an muproteseted tile empties with a fall, even thongh only two or three feet, the pipe will be molermined and will dron down one hy one mutil, in many ases, a large ditch or gully is washerl hark loor some distance into the field.

It is well to construet the last 15 feet of the outlet main of hell and spigot sewer pipe and to erment the joints. Hu adelition, a concrete or masomy heatwall shoutel be built alomel the end of the last tile. If sueh a headwall is rarred down at trast two or three feet into the gromet, it will not be easily undermined, espeedally if a smitable apron or floor is provieled to prevent aresion cansed ly the water falling from the drain. Sueh aluens or lloors may be made of the same material as the headwall, or for small drains they may be marle by filling in below the ontlet tile with loose stomes and houlders large enough to remain in place.

For small dratus esperedally it is sometimes advisalbe to eover the ontlet with a grating of small bals to prevent the entrance of small ground animals.

\section{COST DATA.}

The mit prices for both the materiak and the construetion of drains vary so greatly from year to year, and in different localities, that it 
is impossible to aceurately estimate the cost of the work of one job or one vear at the mit prices of previons work. 'The data tabulated here are average values and are only suffieiently accurate for approximate estimates. The mere fact that the bid on any partienlar job varies from the prices given here should not be taken as evidence that either these prices or those of the bid are incorrect or unjust.

\section{ESTIMATE OF TILE REQUIRED PER ACRE.}

Table I shows the amount of tile recuired lor the lateral system providing the laterals are laid at equal distances andert. This table and the cost tata will make possible an approximate estimate of the probable cost of the laterals of the proposed system. Tho this must be added the estmiate of the cost of the main and the submains.

\section{'TABLE I.}

\section{TILE REQUIRED PER ACRE FOR LATERAL SYSTEM}

$\begin{array}{cc}\text { Distance between } & \text { Linear Feet of } \\ \text { Laterals-Feet } & \text { Tile per acre. } \\ 20 & 2,178 \\ 25 & 1,742 \\ 30 & 1,452 \\ 33 & 1,320 \\ 40 & 1,089 \\ 50 & 872 \\ 66 & 660 \\ 80 & 545 \\ 100 & 436 \\ 150 & 291 \\ 200 & 218\end{array}$

\section{COST OF DRAIN TILE.}

Table II gives the average prices of drain tile in lowa on Jan. 1st, 1917. The prices of clay drain tile are usually puoted on ear-load lots delivered at points laving an average freight rate. In general the landowners of lowa are sufficiently close to ctay tile factories to come within the zone of this average freight rate. The prices of eoncrete tile, on the other hand, are ordimarily quoted f. o. b. cars at the factory. The pricess given are averaged from those of several factories. Hence in using this table for estimatiog, the eost of the concrete tile f. o. b. the factory must be increased by the anomut of the freight from the factory to the point of usage. For purposes of eomparison the price of concrete tile delivered has been computed by adding to the puoted price the charge for a 100 mile freight haml.

These prices a pe approximately correct average prices on Jannary 1, 1917, but they will probably not agree exactly with those quoted at that 
TABLE II

\section{AVERAGE PRICES AND WEIGHTS OF DRAIN TILE. IN IOWA (JAN. 1, 1917.)}

\begin{tabular}{|c|c|c|c|c|c|c|}
\hline \multirow[b]{2}{*}{$\begin{array}{c}\text { Dlam. } \\
\text { of } \\
\text { Tile } \\
\text { Inches }\end{array}$} & \multirow{2}{*}{ Price } & 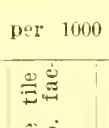 & $\begin{array}{l}\text { Feet } \\
\frac{2}{2}\end{array}$ & \multicolumn{2}{|c|}{$\begin{array}{l}\text { Weiglut, Llus, } \\
\text { ver Foot }\end{array}$} & \multirow[b]{2}{*}{ Cost of Hauling- Price per Ton. } \\
\hline & & 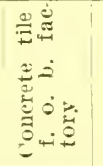 & 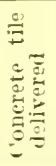 & $\begin{array}{l}\stackrel{2}{=} \\
\frac{\pi}{2}\end{array}$ & 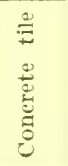 & \\
\hline
\end{tabular}

\begin{tabular}{|c|c|c|c|c|c|c|c|c|c|}
\hline$\frac{4}{5}$ & $\$$ & 20 & $\$$ & 28 & $\mathrm{~s}$ & 33 & 8 & 10 & First mile including loarling ant unloading, \\
\hline 6 & & 30 & & 37 & & 43 & 10 & 13 & \\
\hline 7 & & 50 & & 17 & & 5.5 & 12 & 17 & Fach adilitional mile, $\$ 0.25$ to $\$ 0.50$. \\
\hline 8 & & $i^{2}$ & & 58 & & is & 1.5 & $2 \cdot 2$ & \\
\hline 10 & & $1 \%$ & & $8 !$ & & 1038 & 25 & 311 & \\
\hline 12 & & 135 & & 117 & & $1: 37$ & $: 3$ & 15 & \\
\hline 14 & & 20.5 & & 17.5 & & 2013 & 4.5 & $5 x$ & \\
\hline 15 & & 345 & & $2(x)$ & & $2: 33$ & 30 & fis & \\
\hline $16 ;$ & & 285 & & 240 & & $27 !$ & (1.5 & 83 & \\
\hline 18 & & 345 & & 3.5 & & 375 & (i) & 115 & \\
\hline 20 & & 500 & & 40.5 & & 417 & 55 & 130 & \\
\hline $2 \cdot 3$ & & (itt) & & 480 & & 5.44 & 9.5 & 1,5 & \\
\hline 24 & & 715 & & 6001 & & fis6 & 110 & 1811 & \\
\hline 26 & & 875 & & fien & & 793 & 135 & 215 & \\
\hline 25 & & 1025 & & 500 & & $(1.23$ & $11+5$ & 255 & \\
\hline 30 & 1 & 1250 & & 900 & & 11137 & 300 & 285 & \\
\hline
\end{tabular}

Freight rates on drain tile in car-load lots, Jan, 1, 1917; 100 miles $\$ .048$ per 100 ib.

75 miles ...044 per $100 \mathrm{lb}$.

50 miles ..040 ner $100 \mathrm{lb}$.

All prices, including freight charges, on Jan. 1, 1919, were about 25'; higher than those given above.

time by any one factory. "The cost of production of all tile has inereased materially during the past year. The eoming season may see either an increase ol a decrease in prices, and such thanges must be taken into eonsideration in using the data in this tahle.

The prices given in this table will usually be too large for estimating cost of tile for a eomnty drainage distriet. The latge amount of work let in one contract in that case often seecures somewhat lower priees.

The data as to eost of hauling tile are but approximately average. This eost will vary considerably with the methods used and the condition of the roads. Howevere, this iten is often of minor importance as the lanklowner "an usmally do the hauling with his own teams during the seasons when they are not needed for other work. 'The eost given in Table III are believed to be fairty average and valuable for preliminiary estimates.

COST OF DIGGING THE TRENCH. LAYING TILE AND BACK FILLING.

The prices for drainage construetion given in Table III will vary considerably from the actual rosts on any one system, the amomt and direction of the variation depending upon the size and location of the system, the soil formation, and the methods by which the trenching and back filling are done. However, they are average values of suffieint accuraey for preliminary estimating. 


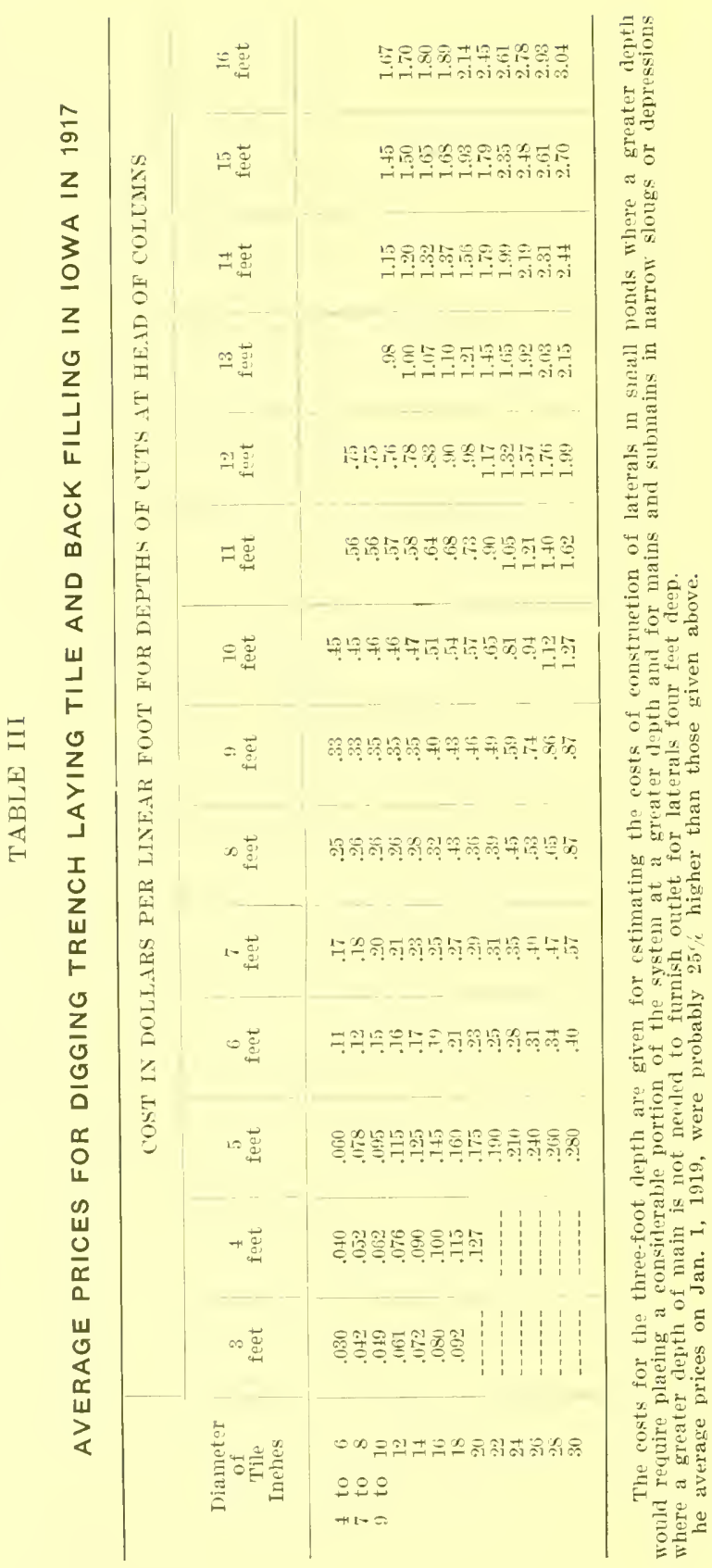




\section{BULLETINS OF THE ENGINEERING EXPERIMENT STATION}

- No. 1. The Iowa State College Sewage Disposal Plant Investigations.

* No. 2. Bacteriological Investigations of the Iowa State College Sewage.

* No. 3. Data of Iowa Sewage and Sewage Disposal.

*No. 4. Bacteriological Investigations of the Iowa State College Sewage Disposal Plant.

*No. 5. The Chemical Composition of the Sewage of the Iowa State College Sewage Disposal

Plant.

*No. 6. Tests of Iowa Common Brick.

* No. 7. Sewage Disposal in Iowa.

* No. 8. Tests of Dry Press Brick Used in Iowa.

* No. 9. Notes on Steam Generation with Iowa Coal.

*No. 10. Dredging by the Hydraulic Method.

* No. 11. An Investigation of Some Sewage Disposal Systems.

* Vol. II. No. 6. The Good Roads Problem in Iowa.

* Vol. III. No. 1. Tests of Cement.

* Vol. III. No. 2. State Railroad Taxation.

* Vol. III. No. 3. Steam Generation with Iowa Coals.

Vol. III. No. 4. Incandescent Lamp Testing.

* Vol. III. No. 5. Steam Pipe Covering Tests.

* Vol. III. No. 6. The Assessment of Drainage Districts.

Vol. IV. No. 1. Tests of Iowa Limes.

Vol. IV. No. 2. Holding Power of Nails in Single Shear.

Vol. IV. No. 3. Miracle Contest Papers for 1908. (Theses on Cement and Concrete.)

Vol. IV. No. 4. Miracle Prize Papers for 1909. (Theses on Cement and Concrete.)

Vol. IV. No. 5. Sanitary Examination of Water Supplies.

Vol. IV. No. 6. Sewage Disposal Plants for Private Houses.

Bulletin No. 25. Electric Power on the Farm.

Bulletin No. 26. The Production of Excessive Hydrogen Sulfid in Sewage Disposal Plants and Consequent Distintegration of the Concrete.

Bulletin No. 27. A Study of Iowa Population as Related to Industrial Conditions.

Bulletin No. 28. History of Road Legislation in Iowa.

bulletin No 29. Costs of Producing Power with Iowa Coals.

Fulletin No. 30. The Determination of Internal Temperature Range in Concrete Arch Brideres.

Bulletin No. 31. The Theory of Loads on Pipes in Ditches, and Tests of Cement and Clay Drain Tile and Sewer Pipe.

Bulletin No. 32. A Topographical Survey of the Spirit Lake and Okoboji Lakes Region.

Bulletin No. 33. House Heating Fuel Tests.

Bulletin No, 34. The Use of Iowa Gravel for Concrete.

Bulletin No. 35. The Iowa Engineering Experiment Station and its Service to the Industries of the State.

Bulletin No. 36. Report of the Investigations on Drain Tile of Committee C-6, American Society for Testing Materials.

Bulletin No. 37. Iluminating Power of Kerosenes.

Bulletin No. 38. Electric Central Station Operation in Iowa.

Bulletin No. 39. Good Roads and Community Life.

* Bulletin No. 40. An Investigation of Iowa Fire Clays.

Bulletin No. 41. Sewage Treatment for Village and Rural Homes,

Bulletin No. 42. A Study of Oil Engines in Iowa Power Plants.

Bulletin No. 43. Practical Handling of Iowa Clays.

Bulletin No. 44. Locomotive Tests with Iowa and Illinois Coals.

Bulletin No. 45. Investigations of Gravel for Road Surfacing.

Bulletin No. 46. Electric Pumpine, with Results of Tests and Operating Records.

Bulletin No. 47. The Supporting Strength of Sewer Pipe in Ditches, and Methods of Testing Sewer Pipe in Laboratories to Determine their Ordinary Supporting Strength.

Bulletin No. 48. The Early Purchase and Storage of Iowa Coal.

Bulletin No. 49. An Investigation of Tests of Iowa Shale Drain Tile.

Bulletin No. 50. The Theory of Underdrainage.

Bulletin No. 51. Recommendations for Farm Drainage.

*Out of print.

Bulletins not out of print may be obtained free of charge upon request addressed to The Director, Engineering Experiment Station, Sta. A, Ames, Iowa. 


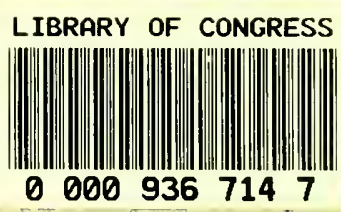

\section{The College}

The Iowa State College of Agriculture and Mechanic Arts conducts work along five major lines:

\section{AGRICULTURE \\ ENGINEERING \\ HOME ECONOMICS \\ INDUSTRIAL SCIENCE \\ VETERINARY MEDICINE}

The Graduate Division conducts advanced research and in. struction in all these five lines.

Four, five and six year collegiate courses are offered in different divisions of the College. Non-collegiate courses are offered in agriculture, engineering and home economics. Sum. mer Sessions include graduate, collegiate and non-collegiate work. Short courses are offered in the winter.

Extension courses are conducted at various points throughout the state.

Research work is conducted in the Agricultural and Engineering Experiment Stations and in the Veterinary Research Laboratry.

Special announcements of the different branches of the work are supplied, free of charge, on application. The general catalogue will be sent on request.

Address The Registrar,

Ames, Iowa. 